\title{
Co-producing early years policy in England under the Coalition Government
}

\author{
Eva Lloyd \\ The Cass School of Education and Communities, London, UK
}

\begin{abstract}
During the first half of the current Coalition Government, co-production - a form of participatory governance - was implemented widely in the conceptualization, design and implementation of early years policies. Seen as a revolutionary approach to public service reform, resulting in more effective and more cost-effective public services, the joint approach to co-production by the Department for Education and the Department of Health built on the Labour Government's strategy to involve 'active citizens' as stakeholders in public policy development. Local authority early years managers, directors of children's services and education trade union officers were among education sector stakeholders involved in this process. Co-production is defined here as sharing features of two models of participatory governance identified by Skelcher and Torfing (2010) in their institutional taxonomy of this concept. The actual experience of co-producing early childhood policy suggests that politics may trump policy-making, despite a high-level commitment to co-production.
\end{abstract}

\section{Keywords}

co-production, early years policy, early years stakeholders, participatory governance, public service reform

\section{Introduction}

During the first half the Coalition administration, between autumn 2010 and spring 2013, co-production, a form of participatory governance, was implemented widely in the conceptualization, design and implementation of early years policies. Before analysing this process in more detail, its wider political and policy context will be explored. When co-production was introduced by the Department for Education (DfE) and the Department of Health (DH) for early years policy development, the participation of civil society in public policy development at central or local levels had already acquired a considerable history within European Union member states.

The EU in its 2001 White Paper (Commission of the European Union, 2001) acknowledged that the production of more effective and relevant policies requires being informed by the direct knowledge and competences of citizens and civil society organizations. Therefore participation in governance should be regarded as much as a pragmatic necessity as a form of policy legitimization within democratic societies. At around the same time OECD published its handbook on citizen involvement in policy-making (Gramberger, 2001). Participatory governance as a means to enhance 'democratic governance' (Skelcher and Torfing, 2010: 71) had become an idea whose time had come.

The 2001 EU White Paper identified five principles underpinning good - defined as more democratic - governance: openness, participation, accountability, effectiveness and coherence. While recognizing that each principle was important by itself, the EU White Paper nevertheless stressed that all should be applied in a more inclusive way at all levels of government (Commission of the European Union, 2001: 10). There was a need to replace the prevailing linear model of policy implementation 'from above' with a 'virtuous circle' of feedback and involvement at all levels of the policy cycle (Commission of the European Union, 2001: 11). Although the proposed innovations were in the first instance tailored to apply to the various institutions making up the European Union, by implication member states should follow the example set. Certainly the principle of participatory governance was readily adopted by the incoming UK Labour Government in 1997.

Under three successive Labour administrations, 1997/ 2001, 2001/05 and 2005/10, the concept of participatory governance was translated into a number of different practices, as part of Labour's policy renewal agenda (Barnes et al., 2007). The concept of citizens as stakeholders as opposed to that of citizens as voters (Skelcher, 2005) was embraced enthusiastically by the new government as part of Labour's public service reform agenda. A raft of strategies for involving 'active citizens' in local policy-making was developed (Barnes et al., 2007). Not all appear to have been equally successful.

A study for the Joseph Rowntree Foundation focusing on co-production among people out of work both inside and outside public services (Boyle et al., 2006) highlighted the 
contribution such involvement could make to the development of 'social capital', but it did not address co-production of policy. Gains in terms of the growth of autonomous networks and governance arrangements from such partnership working with local government across public policy areas were questioned in a comparison of England and Scotland; the study concluded that '.. . the state through policy asymmetries retains a powerful role' (Fenwick et al., 2012: 417).

In relation to early childhood policy, Penn and Randall (2005) focused on Labour's promotion of local partnerships in early childhood policy implementation and on the barriers to success generated by these resource-intensive processes. They also highlighted how such partnerships actually built on a model developed under the previous Conservative government.

During the period Labour was in office there was a rapid proliferation of policy networks, policy think tanks and 'public intellectuals' whose influence made itself felt in the modernization of public policy, as Ball and Exley (2010) illustrated in relation to Labour's education policy developments. Today, the broad notion of participatory governance, defined by Hallsworth and Rutter (2011: 8) as 'responsive external engagement' in a report for the London-based think tank, the Institute for Government, appears to have secured its permanent inclusion among the fundamentals of good policy-making in the UK. As such it was adopted by the Coalition Government from 2010. In the course of the last decade the concept of coproduction, the subject of this article, gained prominence as part of such developments.

\section{The co-production concept and its history}

The history of the concept of co-production reveals its origins in the work of Nobel prize winning political economist Elinor Ostrom in the USA (Ostrom, 1996), while the work of Putnam (2000) and Cahn (2001) has also been influential. According to a recent edited work on co-production as an innovation in public governance (Pestoff et al., 2012), the concept has been around for decades but has recently experienced a 'revival' internationally.

Tracing the exact point at which the concept of coproduction was first introduced into UK public policy discourse proved difficult. From around 2005 it began being promoted in publications and media activities emanating from the think tank New Economics Foundation and from Nesta, the national innovation charity set up in 1998. In a 2009 Nesta report, Boyle and Harris announced:

There is no doubt that the idea of 'co-production' has arrived in the UK. Policymakers are using the term in their speeches, and it is increasingly appearing in Whitehall strategy documents and think-tank reports. Boyle and Harris (2009: 3)

In the same year, the Cabinet Office, in accordance with its role to promote the effective development, coordination and implementation of policy and to transform the delivery of services, chimed in with a definition of co-production in an on-line discussion paper:

Co-production is a partnership between citizens and public services to achieve a valued outcome. Such partnerships empower citizens to contribute more of their own resources (time, will power, expertise and effort) and have greater control over service decisions and resources.

(Horne and Shirley, 2009: 3)

Summarizing the claims made for it in another report from Nesta and partner agencies (Boyle at al., 2010), the authors noted that co-production was seen as a revolutionary approach to public service reform embodying a model of 'deliberative democracy'. It amounted to a way of sharing the design and delivery of public services with service users and representative agencies. The results, co-produced services, were claimed to be more effective for the public and more cost-effective for policy-makers.

To test these claims, this article explores how from 2010 onwards the DfE and DH employed co-production for almost 2 years to articulate and implement early childhood policy. However, in order to understand better where co-production fits in as a form of participatory governance and to assess its role, it may be helpful to locate it first within a wider conceptual framework developed by British researchers.

\section{Co-production as a model of participatory governance}

What, then, is the wider conceptual framework within which co-production is embedded? A study of democratic governance in Europe by Skelcher and Torfing (2010) may prove helpful. These authors introduced some theoretical perspectives on 'participatory governance' as a model of policy consultation, development and implementation. As part of developing a research agenda in this area, the authors constructed an institutional taxonomy for participatory governance. They started from the premise that:

\begin{abstract}
... the involvement of citizens-as-stakeholders in and through institutional forms of participation will contribute to a responsible production of relevant policy outputs and outcomes through active engagement and democratic deliberation.
\end{abstract}

(Skelcher and Torfing, 2010: 76)

In their study they distinguished between four broad institutional forms of citizen participation aiming at effective and democratic governance of contemporary European societies: (i) opinion-seeking through public consultation; (ii) data-gathering though public surveys; (iii) policyexploration through deliberative forums; and (iv) interactive dialogue through governance networks. Whereas the first two forms will probably be immediately familiar, the second two may benefit from further definition here (Skelcher and Torfing, 2010: 80).

The description of the process of policy exploration through (iii) deliberative forums noted that it occurs when: 
A randomly selected group of individual citizens or a politically selected group of civil society organisations is sometimes invited to participate in a structured dialogue with each other and with relevant experts and policymakers about sensitive policy issues in order to produce relevant and informed policy advice.

(Skelcher and Torfing, 2010: 81)

Examples provided of typical forms of this type of policy exploration include citizen forums, future or scenario workshops and consensus conferences. The fourth institutional form, interactive dialogue through governance networks, deviates from the third model in several respects, including its driving force:

Interdependent but operationally autonomous actors from the public and private sectors interact through relatively self-regulated negotiations to identify policy problems, formulate policies, and/or implement joint solutions. These interactions are often termed policy or governance networks.

(Skelcher and Torfing, 2010: 81)

Examples provided of typical forms of such networks include permanent monitoring and advisory committees with citizen participation and formally organized foresight, policy or implementation networks. Besides profiling the type of citizen involved in such processes and their level of participation, Skelcher and Torfing's taxonomy also defined the degree of institutionalization of the process in question and the influence of the participating actors.

As well as displaying a considerable degree of (in)formal institutionalization, the actors within deliberative forums were seen to have considerable popular influence, with possible unpredictable consequences for government '... as deliberative processes are difficult to control' (Skelcher and Torfing, 2010: 83). For governance networks both the degree of (in)formal institutionalization and influence, based on either interest mediation or co-governance, were seen as high.

As will become apparent in the following sections, early childhood policy co-production shared features of both these forms of participatory governance, but had unique characteristics as well. Given its genesis as a government-initiated process, it could be regarded primarily as a form of policy exploration though a deliberative forum.

\section{Co-production in early childhood policy-making}

In late 2009 a small number of senior individuals within the early childhood sector, including the author of the present article, received an invitation to join a high-level advisory group convened by ministers at the DfE and the $\mathrm{DH}$. From its January 2010 inaugural meeting onwards, the group was to explore pathways for the implementation of the Coalition priorities for early years as laid down in the DfE Business Plan, underpinned by the outcomes of the Comprehensive Spending Review and the Coalition Government's key principles for public service reform.
On the now archived pages of the DfE website the role of what came to be called the Co-production Steering Group was described in early 2011 as follows:

Since the beginning of 2011 a steering group has been working with the Department for Education and the Department of Health to advise on a new Government vision for the foundation years ... The Government is committed to 'co-producing' this vision, and working collaboratively on the detailed policy and implementation questions which will follow. We want a system that is led by the professionals who understand how best to deliver these services - we have been working closely with experts in the early years sector to produce our publication, collaborating on a new vision for the crucial foundation years of each child's life. This partnership is what we are calling coproduction, and we hope to see it continue and gain in strength after publication. (DfE, 2011)

This text appeared to reflect a strong official commitment to the process of co-production. The mode of operation characterizing this process involved face-to-face working meetings of sector specialists, supported and informed by civil servants detailed to service this steering group, whose chairing rotated amongst its members. It was emphasized by DfE and DH officials from the start that membership would be on a personal basis, rather than as formal representatives of organizations or networks. It was understood, however, that group members would take back issues under discussion to their respective constituencies for information-sharing, debate and advice.

The group's remit as formulated for the benefit of the early years sector was threefold: to champion coproduction as a way of working; to give strategic thought to big policy issues relevant to the Families in the foundation years policy document under construction; and to provide some accountability to the sector by monitoring and advising on implementation issues and acting as one of several conduits for feedback from the sector.

The 'foundation years' publication referred to in the DfE website quote above eventually turned into two separate web-based documents, published in July 2011: Families in the foundation years was aimed at parents (DfE and DH, 2011a), whereas Supporting families in the foundation years was aimed at the professionals commissioning, leading and delivering services for parents during pregnancy and for children up to the age of 5 (DfE and DH, 2011b). The evidence underpinning this policy statement was also published online (DfE and DH, 2011c).

The Coalition Government's first statement on early childhood policy was certainly produced in very close cooperation with the steering group's original 11 members, listed by Morton (2011). Two of these were senior DfE and DH officials at director level. In total it was to meet for 11 , mostly full-day, meetings between January 2010 and March 2013, but other emerging co-production groups had also had an input.

Even before these policy statements' 2011 publication, a network of satellite working groups to the co-production 


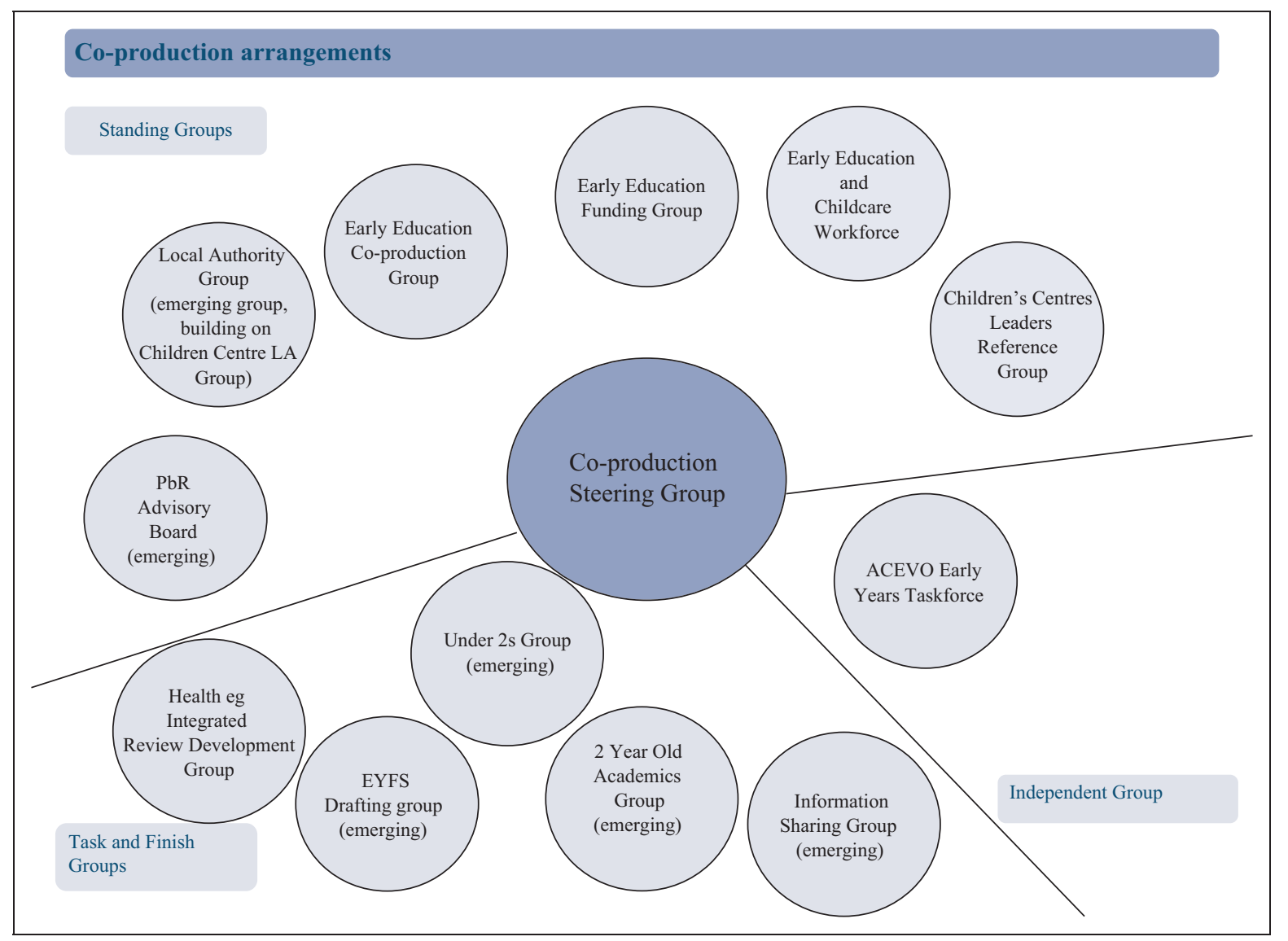

Figure I. Co-production arrangements.

steering group was being established to consider particular policy questions and make an active contribution to policy implementation. Figure 1 (Haywood, 2011) is a diagram of the network of standing groups, task and finish groups and existing groups associated with the co-production process that had emerged by late 2011. One of them was entirely devoted to workforce issues, for instance (Faux, 2011); aspects of the work programme of the Early Education Co-production Group, co-chaired by the author of the present article, are illustrated in Table 1.

The high-level membership of the latter group, which met for 13 whole days between March 2011 and July 2012, was representative of and sometimes overlapping with other co-production groups. It included 11 senior members of the early years sector - both leaders and managers - supported by a range of civil servants from both government departments. Among the sector members were local authority early years managers, directors of children's services, members of education-related professional organizations, trade union officials, academics, and CEOs of national early years membership and campaigning organizations, although the involvement of health officials was always limited.

The information presented here on the co-production process should convey a good impression of its scale and its scope, its value as well as its potential financial implications, not only for the two government departments, but also for group members' organizations in terms of time and effort expended. Given this input and commitment, the next steps in the process came as somewhat of a surprise, at least to early years sector participants in the various groups.

\section{Early childhood co-production and politics}

By the summer of 2012 the role played by DH officials had become minimal and DfE had by default become the lead department driving the co-production process. In July, DfE officials first presented unexpected new proposals for the groups' amalgamation to the Co-production Steering Group, and subsequently to other groups. Soon it became clear that the matter in question was already settled. There would be one co-production group as a standing group, which would act as a 'critical friend' to the Department (DfE) and would bring together independent external perspectives. Alongside this group a series of more focused task and finish groups would be operating; this would include some groups that had previously been standing groups, such as the workforce and funding co-production groups. Again, membership would be on a personal basis.

The first meeting of the 'integrated' co-production group took place in October 2012. The next meeting did not take place until March 2013, when the group was told by DfE officials that it was being stood down. There were to be no more standing groups advising the minister on early childhood matters. The existing and 'new' task and finish groups illustrated in Figure 1 ended their operations within 
Table I. Work programme Early Education Co-production Group March 201 I - July 2012.

\begin{tabular}{|c|c|}
\hline Policy formation & Policy implementation \\
\hline Informing foundation years policy statement & Informing implementation early education vision \\
\hline $\begin{array}{l}\text { Informing the streamlining of statutory guidance - 'code of } \\
\text { practice' }\end{array}$ & Helping to draft the autumn 201 I early education consultation \\
\hline $\begin{array}{l}\text { Reviewing local authority childcare sufficiency reporting } \\
\text { duties under section II of the } 2006 \text { Childcare Act }\end{array}$ & $\begin{array}{l}\text { Developing strategies for raising parental education entitlement } \\
\text { awareness, especially for disadvantaged parents }\end{array}$ \\
\hline $\begin{array}{l}\text { Considering the shape of the } 2 \text {-year-old early education } \\
\text { offer }\end{array}$ & $\begin{array}{l}\text { Supporting the implementation of the revised Early Years Foundation } \\
\text { Stage programme and the associated educational materials }\end{array}$ \\
\hline Reviewing the Early Years Single Funding Formula (EYSFF) & $\begin{array}{l}\text { Acting as reference group for the NAO }(2012) \text { study of the delivery of } \\
\text { the free early education entitlement }\end{array}$ \\
\hline
\end{tabular}

six months or so from July 2012; at the time of writing, only the early education funding group continues to meet.

In the meantime, there had been a significant change at the DfE. In the September 2012 ministerial reshuffle, Elizabeth Truss MP, a Conservative, took over responsibility for early years policy from Sarah Teather MP, a Liberal Democrat. From an earlier publication by Truss when she was deputy director at the right-leaning think tank CentreForum (Truss, 2012), it was clear that childcare provision was high on her agenda as opposed to early education and wider family support services.

It was perhaps remarkable that during the period in which co-production was actively employed as a support to early years policy formulation, the groups' input had not been sought in respect of several major early years policy implementation developments. For instance, preparations for and implications of the September 2011 move to a single annual intake into primaries, leading to most 4 year olds now being in school, had not been discussed within the groups, although the Early Education Co-production Group urged for it to be put on the group's agenda, which eventually it was.

Moreover, a total surprise to the co-production teams was the Chancellor of the Exchequer's 2011 Autumn Statement announcement of the extension of the early education entitlement to 40 per cent of 2 year olds by $2014 / 15$, i.e. to 260,000 disadvantaged English children. However, support from several groups was immediately enlisted to consider the major implementation issues notably arising from this unexpected development.

In January 2013, even before the co-production process had been 'officially' terminated, the first early years policy statement produced under the new DfE regime was published (DfE, 2013). Clearly by this stage co-production was no longer considered a key concept in the development of public services. The document had not been co-produced and neither was it successor (HM Government, 2013), published in July of the same year. Within 2 years the term 'foundation years' had been relegated to the dustbin of history. Only the 2011 Foundation years document aimed at professionals can still be easily traced on the DfE website.

This downgrading, if not outright demise, of the coproduction process did not go unnoticed. In April 2013 the Opposition in the Commons asked the Secretary of State for Education in a written question to list the meetings convened of the Early Education Co-production Group since January 2011 as well as any meetings with its individual members.
The written response by the responsible DfE minister Elizabeth Truss provided the dates of the 12 steering group meetings convened since January 2011 and those of the 13 Early Education Co-production Group meetings. The reply also noted that:

Ministers, special advisers and officials have had numerous bilateral and multilateral meetings with members of the Early Education Co-production group, as well as with others with an interest in early years and child care policy, in the period since January 2011 and continue to do so.

(Hansard, 2013a)

This statement, only verifiable by a freedom of information request, was followed by further disaggregated information in another parliamentary written answer (Hansard, 2013b). This revealed that ministerial discussions with parties did not reflect the composition of the co-production partnership.

This is not the place for an assessment of any qualitative differences between the two sets of policy documents - one co-produced and the other without such stakeholder input. However, the nature of the 2013 proposals for reform generated much heated discussion and campaigning in the early years sector (Morton, 2013), quite unlike the benign reception afforded to the first Coalition Government's early years policy statement. It is tempting to speculate that co-production might have made a difference. How could the reversal of the decision to deploy co-production widely in early years policy formation be explained from a theoretical perspective?

\section{Conclusion: Implications for leadership and management}

Did the episode of co-producing early childhood policy reported on here confirm the claims for the process's value cited in the early sections of this article? In order to determine whether it added value for leaders and managers as well as for policy-makers and for the policies themselves, the political context in which policy-making takes place cannot be ignored.

Even the most ardent supporters of co-production acknowledged that the process might get blocked as a direct result of its inherent strengths, ' $\ldots$. because it takes seriously the current political rhetoric about 'devolving power' 
and 'empowering communities' (Boyle et al., 2010: 3). Skelcher and Torfing (2010: 88) also warned of the potential impact of the, ultimately skewed, power dynamics characterizing the process, ' ... which may generate compromises by actors or the exercise of authoritative rule by power holders'.

On the basis of evidence presented here, it could be argued that co-production shares features of the third and fourth models of participatory governance recognized by these authors. They did critique these from a wider perspective, including that of policy-makers themselves. While they recognized that these two models provided true opportunities for 'empowered participatory governance', they might also pose problems of 'meta governance', i.e. of control, for governments (Skelcher and Torfing, 2010: 82). This was a particular risk if the process was initiated by civil society, representing a 'bottom-up' approach. In respect of governance networks in particular, they concluded that these might not represent optimal citizens-as-stakeholders' participation for different reasons:

\begin{abstract}
Not only are instruments such as governance networks difficult to initiate, sustain and terminate, but it is also difficult to ensure the participation of citizens who are not organized in formal associations or civil society organizations. In addition, governance networks often suffer from a lack of transparency and accountability.
\end{abstract}

(Skelcher and Torfing, 2010: 82)

However, some of these criticisms can be countered in relation to this particular co-production process. Not only was it definitely organized in a 'top down' manner, and were the policy areas where the groups' input was invited strongly mediated by civil servants, but also information about issues under discussion were also widely disseminated via participants in the process themselves and via the practitioner press (Faux, 2011; Morton, 2011, 2013).

The considerable shift in emphasis within the early childhood policy statements published with and without co-production input points to political influence as a major factor in determining the natural history of what could be termed a co-production 'experiment'. Quite extensive involvement of civil servants in the process may have generated high costs at a time that the DfE's departmental settlement was subject to considerable cost-saving operations, including redundancies (HM Treasury, 2010).

But what about the costs to participants - mostly leaders and managers in public and not-for-profit services and to their organizations? Were these offset by added value from the process? Influencing relevant public policies is a clear priority for both public and private organizations, and the co-production process offered an innovative opportunity to do so. However, the rules of the process meant handpicked senior managers and top leaders from the public and mostly not-for-profit sector got personally involved, rather than delegating this task to professional associations or commercial lobbyists. Although co-production was without doubt an intensive process for the stakeholders involved, who often travelled large distances to attend meetings, in this way some cost-savings could also have been made.

The evidence suggests the process may have generated greater awareness among the early years sector of the power and potential of an alternative group-based influencing mechanism. The realization may have dawned that its potential could well exceed that of web-based surveys and consultations and sometimes indeed that of individual dialogue with civil servants and ministers. Nevertheless, the sudden curtailing of political support for the process may have bred cynicism about the value of participatory governance processes, even among former participants, as evident from the very strong public reaction to the 2013 policy proposals (Jozwiak, 2013). It is hard to imagine this generation of senior public and private sector leaders and managers responding to any future similar initiatives with quite the same commitment and enthusiasm.

Do these speculations also hold for academic participants in this process? From the perspective of the author of the present article, participation was a welcome consequence arising from her role as an applied social scientist specializing in the analysis of early childhood policy-making. After all, applied social research, according to Byrne (2011: 195), is political in its survey, evaluation, legitimation and engagements functions. This implies, among other things, that it provides crucial learning feedback into government systems, and policy impact assessment sets non-ideological criteria for assessing system outcomes and plays a key role in participation and consultation processes. The experience of coproducing early childhood policy under the Coalition Government provided deeper insight into the interface between policy and politics, both in early childhood policy (Lloyd, 2008) and beyond, which should prove beneficial to future applied work as well as to further theorizing.

Certainly, more research is needed to improve academic and policy-maker understanding of the dynamics and the varied effects of participatory governance processes, as Wampler and McNulty (2011: 4) have argued. From an academic perspective, co-production also offered opportunities to further civil servants' understanding of potential and actual policy impacts and absorption of research knowledge. This is an area deserving of thorough investigation in the context of research into informed policy-making (Ouimet et al., 2009).

\section{References}

Ball SJ and Exley S (2010) Making policy with 'good ideas': Policy networks and the 'intellectuals' of New Labour. Journal of Education Policy 25(2): 151-169.

Barnes M, Newman J and Sullivan H (2007) Power, Participation and Political Renewal: Case Studies in Public Participation. Bristol: The Policy Press. 
Boyle D, Clark S and Burns S (2006) Hidden work: Coproduction by people outside paid employment. York: Joseph Rowntree Foundation.

Boyle D, Slay J and Stephens L (2010) Public services inside out: Putting co-production into practice. London: NEF, The Lab and NESTA.

Boyle D and Harris M (2009) The challenge of co-production. London: NESTA.

Byrne D (2011) Applying Social Science. Bristol: The Policy Press.

Cahn ES (2001) No More Throwaway People: The Co-production Imperative. Washington, DC: Essential Books.

Commission of the European Union (2001) European governance: A White Paper. COM (2001) 428 final. Brussels: European Commission.

DfE (2011) Developing a new vision for the early years. London: Department for Education. Available at: http://webarchive.nationalarchives.gov.uk/20130903175547/http://www.education.gov. uk/childrenandyoungpeople/earlylearningandchildcare/dev eloping/a0074569/developing-a-new-vision-for-the-earlyyears (accessed 14 March 2014).

DfE (2013) More great childcare. Raising quality and giving parents more choice. London: Department for Education. Available at: https://www.gov.uk/government/uploads/system/uploads/attachment_data/file/219660/More_20Great_20 Childcare_20v2.pdf (accessed 15 March 2014).

DfE and DH (2011a) Families in the foundation years. London: Department for Education and Department of Health.

DfE and DH (2011b) Supporting families in the foundation years. London: Department for Education and Department of Health. Available at: https://www.gov.uk/government/uploads/system/uploads/attachment_data/file/184868/DFE-01001-2011_ supporting_families_in_the_foundation_years.pdf (accessed 15 March 2014).

DfE and DH (2011c) Families in the foundation years evidence pack. London: Department for Education and Department of Health. Available at: http://media.education.gov. uk/assets/files/pdf/f/families $\% 20$ in $\% 20$ the $\% 20$ foundation $\%$ 20years\%20-\%20full\%20evidence\%20pack.pdf (accessed 15 March 2014).

Faux K (2011) Co-production group will decide direction of workforce. Nursery World, 25 July. Available at: http://www.nurseryworld.co.uk/nursery-world/news/1105504/production-decide-direction-workforce (accessed 13 March 2014).

Fenwick J, Johnston Miller K and McTavish D (2012) Co-governance or meta-bureaucracy? Perspectives of local governance 'partnership' in England and Scotland. Policy \& Politics 40(3): 405-422.

Gramberger M (2001) Citizens as Partners. OECD Handbook on Information, Consultation and Public Participation in PolicyMaking. Paris: Organisation for Economic Co-operation and Development.

Hallsworth M and Rutter J (2011) Making policy better: Improving Whitehall's core business. London: Institute for Government.

Hansard (2013a) Pre-school education. 17.04.2013 Column $481 \mathrm{~W}-482 \mathrm{~W}$. Available at: http://www.publications.parliament.uk/pa/cm201213/cmhansrd/cm130417/text/130417w0 004.htm (accessed 16 March 2014).
Hansard (2013b) Children: day care. 21.05.2013 column 760W$762 \mathrm{~W}$. http://www.publications.parliament.uk/pa/cm201314/ cmhansrd/cm130521/text/130521w0005.htm (accessed 16 March 2014).

Haywood J (2011) Early education and childcare workforce coproduction group. Paper presented at a meeting of the Early Childhood Studies Degrees Network, 2 December.

HM Government (2013) More affordable childcare. London: HM Government. Available at: https://www.gov.uk/government/uploads/system/uploads/attachment_data/file/212671/ More_Affordable_Childcare.pdf (accessed 15 March 2014).

HM Treasury (2010) Spending review 2010. London: HM Treasury. Available at: https://www.gov.uk/government/ uploads/system/uploads/attachment_data/file/203826/Spending_ review_2010.pdf (accessed 16 March 2014).

Horne M and Shirley T (2009) Co-production in public services: A new partnership with citizens. Cabinet Office Discussion Paper. London: Cabinet Office. Available at: http://webarchive.nationalarchives.gov.uk/+/http:/www.cabinetoffice.gov.uk/media/2 07033/public_services_co-production.pdf (accessed 13 March 2014).

Jozwiak G (2013) Professionals condemn 'appalling' childcare ratio plans. Children \& Young People Now. 29 January. Available at: http://www.cypnow.co.uk/cyp/news/1076101/professionals-condemn-appalling-childcare-ratio-plans (accessed 16 March 2014).

Lloyd E (2008) The interface between childcare, family support and child poverty strategies under New Labour: Tensions and contradictions. Social Policy \& Society 7(4): 479-494.

Morton K (2011) Early years expert group to advise children's minister on policy issues. Nursery World, 23 February. Available at: http://www.nurseryworld.co.uk/nursery-world/news/ 1105338/expert-advise-childrens-minister-policy (accessed 14 March 2014).

Morton K (2013) Call for sector day of action on Truss reforms. Nursery World, 3 May. Available at: http://www.nurseryworld.co.uk/nursery-world/news/1097766/sector-day-actiontruss-reforms (accessed 15 March 2014).

National Audit Office (2012) Delivering the free entitlement to early education for three- and four-year-olds. London: NAO. Available at: http:/www.nao.org.uk/wp-content/uploads/ 2012/02/10121789.pdf (accessed 15 March 2014).

Ostrom E (1996) Crossing the great divide: Co-production, synergy, and development. World Development 24(6): 1073-1087.

Ouimet M, Landry R, Ziam S and Bédard P-O (2009) The absorption of research knowledge by public civil servants. Evidence \& Policy 5(4): 331-350.

Penn H and Randall V (2005) Childcare policy and local partnerships under Labour. Journal of Social Policy 34(1): 79-97.

Pestoff V, Brandsen T and Verschuere B (eds) (2012) New Public Governance, the Third Sector, and Co-production. Abingdon and New York: Routledge.

Putnam R (2000) Bowling Alone: The Collapse and Revival of American Community. New York: Simon \& Schuster.

Skelcher C (2005) Jurisdictional integrity, polycentrism and the design of democratic governance. Governance 18(1): 89-110.

Skelcher C and Torfing J (2010) Improving democratic governance through institutional design: Civic participation and 
democratic ownership in Europe. Regulation \& Governance 4(1): 71-91.

Truss E (2012) Affordable quality: New approaches to childcare. London: CentreForum. Available at: http://www.centreforum. org/assets/pubs/affordable-quality.pdf (accessed 15 March 2014).

Wampler B and McNulty SL (2011) Does participatory governance matter? Washington DC: Woodrow Wilson International Center for Scholars.
Corresponding author:

Eva Lloyd, The Cass School of Education and Communities, University of East London, 59 Harberton Road, Upper Holloway, London N19 3JT, UK. E-mail: e.lloyd@uel.ac.uk

\section{Biography}

Dr Eva Lloyd is Reader in Early Childhood in the University of East London's Cass School of Education and Co-director of the International Centre for the Study of the Mixed Economy of Childcare (ICMEC). Her current research focuses on the marketization and privatization of childcare and its impact on service quality, and wider issues around child poverty and social exclusion nationally and internationally. 